\title{
إتمام الحاجة بتعليل حديث عائشة يُّفى في استقبال القبلة حال قضاء الحاجة
}

\author{
أحمد بن عمر بن سالم بازمول \\ كلية الدعوة وأصول الدين قسم الكتاب والسنة جامعة أم القرى - مكة المكرمة
}

\begin{abstract}
ملخص
يهدف البحث إلى دراسة حديث عائشة ثيّفّ في استقبال القبلة حال قضاء الحاجة دراسة تعليلية، والحكم على الحديث ضعفاً أو صحة. تناول البحث الحديث في مقصدين؛ الأول: في تخريجه ودراسة أسانيده، والثاني: في حكم العلماء على الحديث، مع المناقشة والترجيح. جمع البحث كل ما يتعلق بالرواية حسب ما وقف عليه

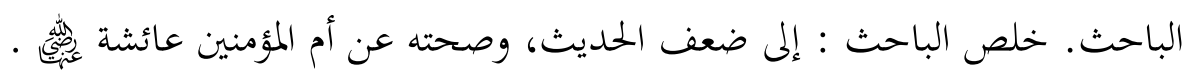
الكلمات المفتاحية: حديث، استقبال القبلة، قضاء الحاجة
\end{abstract}

\begin{abstract}
The article aims to study hadeeth of Aisha (May Allah be pleased with her) On Facing the Qiblah When Fulfilling One's Needs, from the aspect of hidden defects, and thereby coming to a conclusion on its authenticity or lack there of. The thesis is comprised of two parts: The first is (an in depth) reference of all sources of the hadeeth as well as a study of its chains of narration. The second concerns the ruling scholars have given the hadeeth looking at all arguments and concluding with the author's view on the strongest opinion. The article contains everything connected to the narration as per what the researcher was able to find.

The article concludes that the narration is not authentically attributed to the Prophet, peace be upon him, however it is authentic in its narration back to Aisha, may Allah be pleased with her.
\end{abstract}

\section{Keywords: Hadeeth, facing the qiblah, Fulfilling One's Needs.}


الصـواب قال علي بن المـديني :"البـاب إذا لم بتمـع

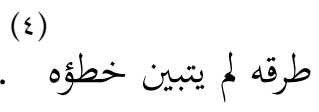

وقــال أبـو إسـحاق إبـراهيم بـن سـعيد

الجوهري :"كل حسديث لا يكون عندي مـن مائة

(०)

وجـه فأنا فيه يتيم" ؛ يريد طرقه وعلله واختلاف

ألفاظه . - (1)

ولقــــــان إدراك العلـة أحسب إلـيهم مـن

استفادة عشرين حديثاً يقول عبدالرحمن بن مهدي "أن أعرف علة حديث؛ هو عندي أحب إلي من بن بن بهرئ

أكتب عشرين حديثاً ليس عندي" "(v)

ولا يستغرب مثـل هـــا الكـلام ؛لأن مـن

الأحاديث مـا تخفى علته فلا يوقف عليها إلا بعد النظر السـديد ومضي الزمن البعيد فها هو الإمـام الججهْبذ نقاد الأحاديث علي بن المديني يقول :"ربـا (^)

أدركت علة حديث بعد أربعين سنة . وهذا يدل على صعوبة هذا العلم ووعورته وأنــ طالبـه لابـــ أن يتحمـل المشــاق والمتاعـب في تحصيله .

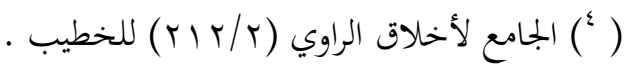

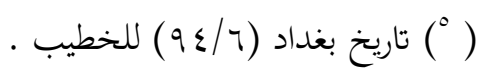

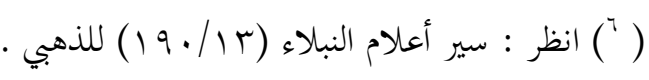

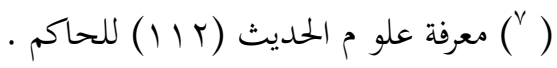

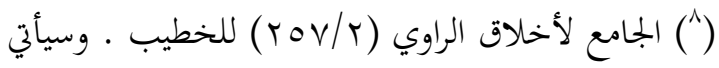
في البحث عن أبي حاتم الرازي نغو هذا.
هذا تخريج معلل لحديث عائشة ئيفّ قالت "ذكـر عنــــــــــل الله قـوم يكرهـون أن يستقبلوا

بفروجهم القبلة فقـال :"أراهـم قـد فعلوا استقبلوا بمقعدتي القبلة". وتظهر أهمية البحث بالأمور التالية - - لتعلقه بمسألة مسألة استقبال القبلة حسال

قضاء الحاجة، وهي مسألة خلافية . - أن فيـه ذباً ودفاعـاً عـن السـنة النبويـة مـن جهة التصحيح والتضعيف.

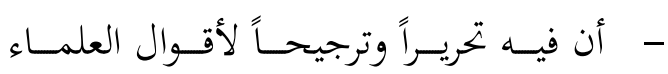

المختلفة بين التقوية والتضعيف ل وتدرك العلة؛ بجمع طرق الحديث، والنظر في اختلاف رواتها، قال الحـافظ أبو بكر الخطيب

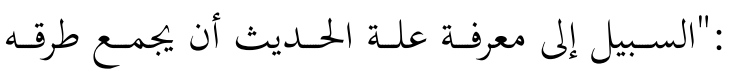
وينظر في اختلاف رواته ويعتبر بمكاغم من الحفظ (r) ومنزلتهم من الإتقان والضبط" .

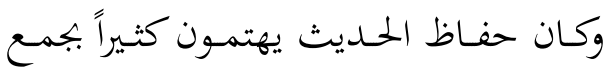
طرق الحديث الواحد لا للتكثير ؛بل لمعرفة الخطأ من

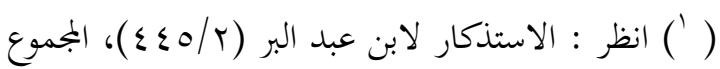

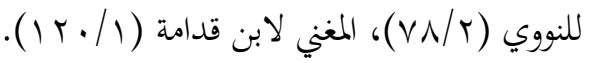

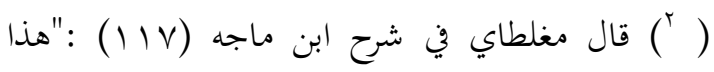
حديث خختلف في تصحيحه وتضعيفه وإرساله ووصله".

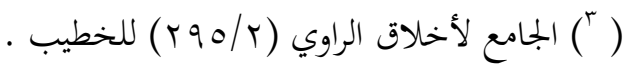


- - ملنـل مـا وقفت عليه مـ كلام العلماء على

$$
\text { الحديث. }
$$

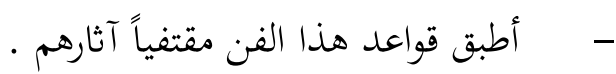

- مأنقل قول مـن ضعف الحـديث أو صححه

$$
\text { مع المناقشة والترجيح. }
$$

و الله تعالى اسأل التوفيق والسداد في الدنيا

والآخرة ، وأن يتقبل مني صالح الأعمال ، وأن يعفو

$$
\text { عن سيئها؛ إنه جواد كريم عفو غفور · }
$$

وصلى الله على عبـده ونبيـه مُحَّه وعلى آله

وصحبه وسلم ومسن سار على دربهم وهجم إلى يوم

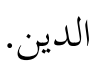

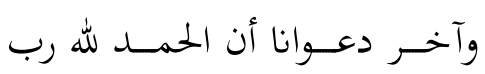

وإذا كانست العلـة في الحسديث لا تـدرك إلا

بعد الوقوف على طرقه وأسانيده؛ فقد قمت بجمع طرق هـا الحـديث مـن الجوامع والسنن والمصنفات والمستخرجات والمسـانيد والمعاجم والأجزاء الحديثية وكتب العلل والتواريخ وكل مـا وقع تحت يدي من كتاب مسند ولا أدعي الإحصاء التام ولكني أدعي بذل كل جهدي في تتبعه وملاحقة أطراف الموضوع ما استطعت إلى ذلك سبيلاً . وقد جعلته في مقدمة، ومقصدين، وخاتمة، وفهرس للمراجع والموضوعات: المقدمــة : ذكـرت فيهـا تسـمية البحــث، وأهميته، وخطة البحث ومنهجه. المقصـــ الأول : تخــيج الحســيث ودراسـة

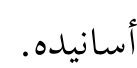

\section{المقصد الأول : تخزيج الحديث ودراسة أسانيده:} روى خالد الحذاء عن خالد بن أبي الصلت عن عراك بن مالك عن عائشة قالت : ذكر عنــ رسول الله قوم يكرهون أن يستقبلوا بفروجهم القبلة فقال :"أراهم قد فعلوا أستقبلوا بمقعديّ القبلة". رواه عن خالد الحذاء جماعة منهم :

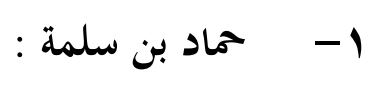

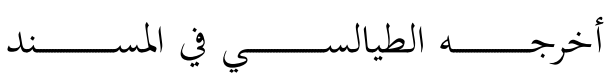

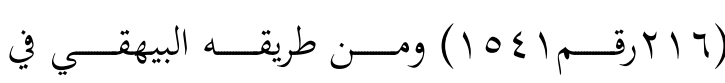

$$
\begin{aligned}
& \text { المقصد الثاني : من أعل الحديث ومن قواه، }
\end{aligned}
$$

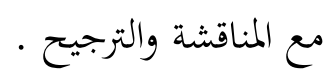

$$
\begin{aligned}
& \text { الخناتمـة : فيهـا خلاصـة البحـث مـع أبـرز } \\
& \text { · النتائج } \\
& \text { وقـــ سـلكت في كتابـة البحــث الخطـوات } \\
& \text { - تبعـت طـرق وأسـانيد هـذا الحـديث على } \\
& \text { حسب ما وقفت عليه. } \\
& \text { - دراسة كل طريق منها على بمفرده مع الحكم } \\
& \text { عليه على ما يتوافق مع قواعد أهل الفن . }
\end{aligned}
$$




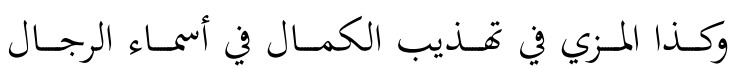

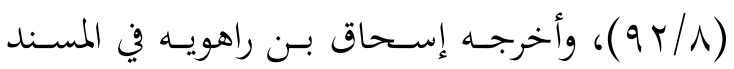

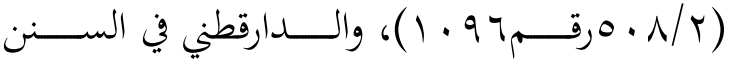

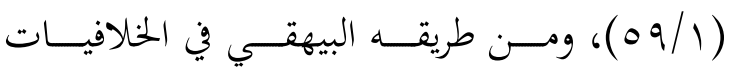

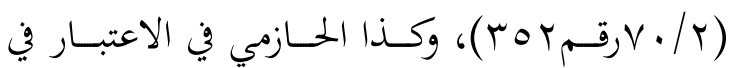
الناسـخ والمنسـوخ (ع آ- 7)، وأخرجـه البيهقي في

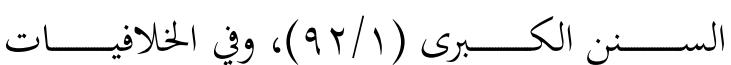

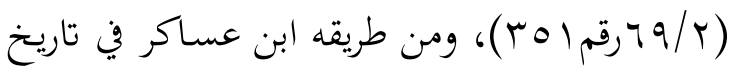

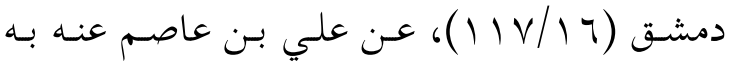
نوه.

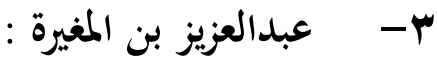

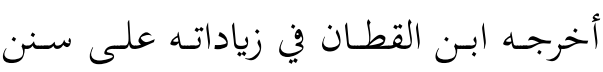
ابن ماجه (1/ • ـ م) من طريق عبدالعزيز بن المغيرة عن خالد الحذاء عنه به نوه.

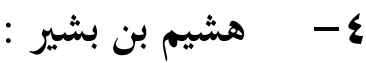

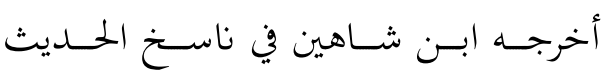
(ع (عرقم من طريق هُشيم عن خالد الحذاء عنه

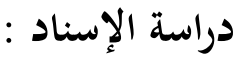

- - خالد بن مهران أبو المنازِل البصري الحذاء، روى له الجماعة، وقال عنه الحافظ في تقريب التهذيب (19 ارقم. 14 1) :"ثقة يرسل ... وقد أشار حماد ابن زيد إلى أن

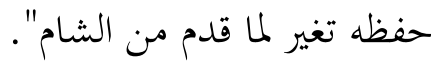

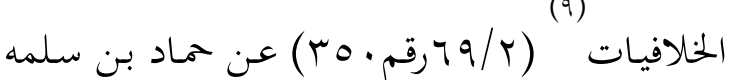
عنه به.

(1.) وأخرجــه ابـن أبي شـيبة في المصـنف

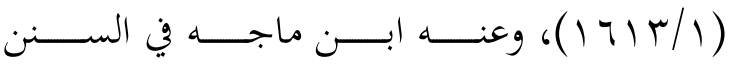

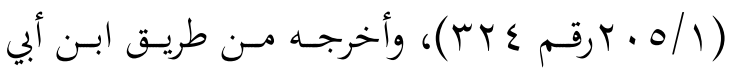
شيبة الدارقطني في السنن (1/ . ؟)، وكذا ابن عبد البر في التمهيد (1/ / / آ)، وأخرجه أحمد في المسند

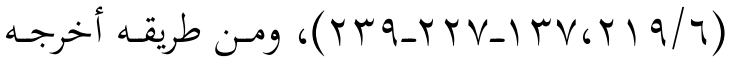
ابن عساكر في تاريخ دمشق (T / V/ I I)، وأخرجه البخاري في التاريخ الكبير (r/Tه 1)، ومـن طريقه أخرجه ابن عساكر في تاريخ دمشق (7 / 1 1 1 )،

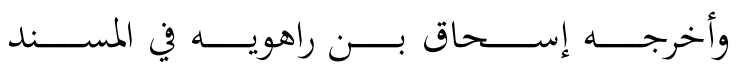

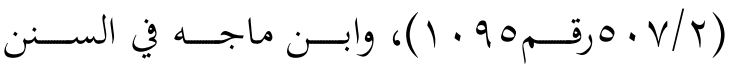

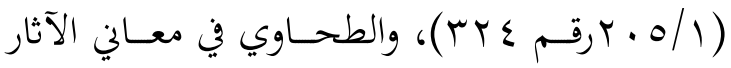

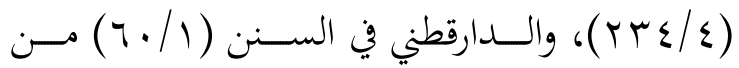
طرق عن حماد بن سلمة عنه به.

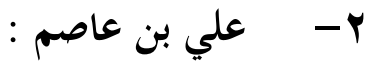

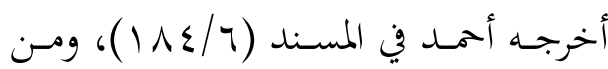
طريقه ابن عساكر في تاريخخ دمشق (1 I V/ I )، (") وقع في الخلافيات "خالد بن الصلت"، وعلق عليه البيهقي بقوله :"كذا قال، وقال غيره : خالد بن أبي الي اليات

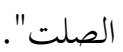
قلت : في مسند الطيالسي " خالد بن أبي الصلت".

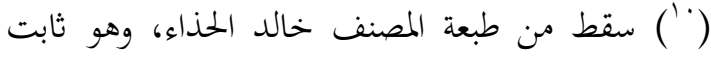

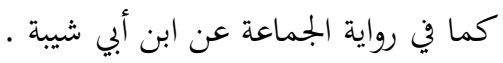


قلت : حمـاد بـن سـلمة عـن خالـد الحـذاء

فقـال رواه غـير واحسد عـن خالـد الحـذاء ليس فيـه سمعت، وقال غير واحسد أيضاً عن حماد بن سلمه له

ل ليس فيه سمعت

قلت : لكن تابع علي بن عاصم حماد بن سلمة عند الدارقطني في السنن (1/ • ฯ) كما أفاده مغلطاي في الإعلام بسنته (1 | I).

فالظاهر أن هذا من أوهام خالد الحذاء، محا يشعر باضطرابه وهذا من علل الحديث.

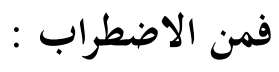

مــا أخرجــهـ ابـنـ أبي شــيبة في المصــف

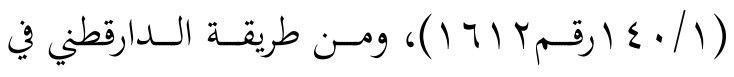

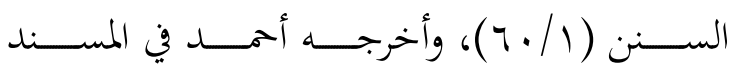

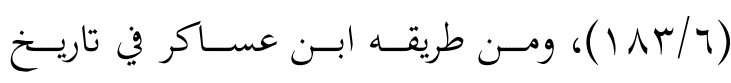

دمشـق (1/1/1 1 1) )، وأخرجـهـ الباغنـدي في مسـند

عمر بن عبدالعزيز (ع اـرقمهو) عن الثقفي .

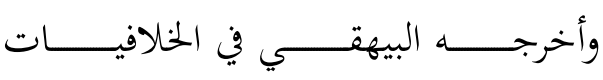

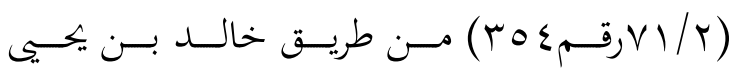

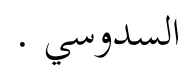

كلاهمـا (الثقفي، والسدوسي) عـن خالـد

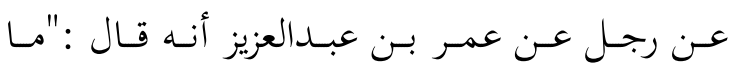

اسـتقبلت القبلـة بفرجـي منـذُ كـذا وكـذا ـ فحـدّث
- خالد بن أبي الصلت البصري المدني الأصل، روى له ابن ماجه وقال عنه

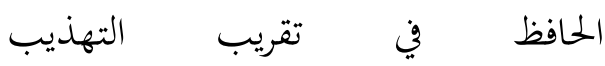

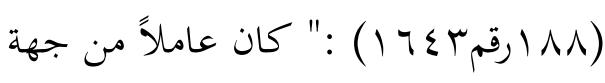
عمر بن عبدالعزيز بواسط وهو مقبول". - عِراك بن مالك الغفاري الكناني المدني، روى له الجماعة، وقال عنه الحافظ في

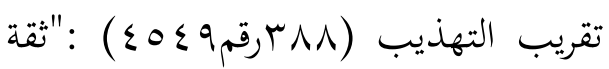

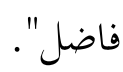

$$
\text { حكم الإسناد : }
$$
فيه خالد بن أبي الصلت مقبول . وفيه انقطاع فعراك بن مالك لم يسمع من

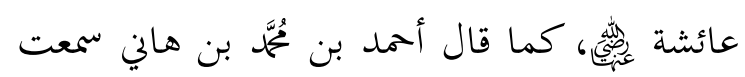
أبا عبد الله وذكر حديث خالد بن أبي الصلت عن عراك بن مالك عن عائشة رضى الله عنها عن النبي قال :"حولوا مقعدي إلى القبلة". فقال : مرسل . فقلست لـه : عـراك بـن مالـك قـال سمعـت عائشة فأنكره . وقال : عراك بن مالك من أين سمع عائشة (11) ماله ولعائشة إنما يروي عن عروة هذا خطأ قال لي : من روى هذا !؟

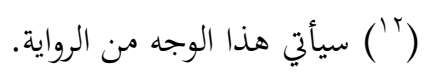
(') المراسيل (rا ارقمج ج) لابن أبي حاتم، وكذا أعله

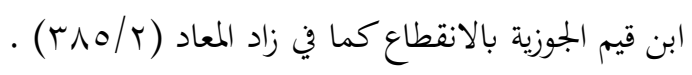




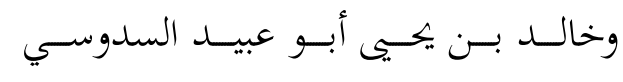

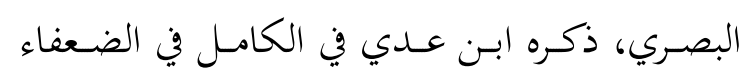

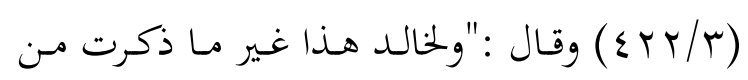

الحسديث إفرادات وغرائب عمن يحـدث عنه وليس

بالكثير وأرجـو أنه لا بأس بـه لأني لمُ أرَ في حديثـه

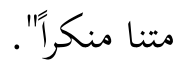

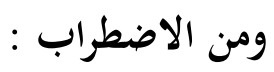

مـا أخرجــه البخــاري في التـاريخ الكبـير

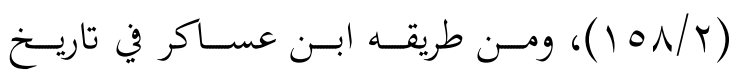

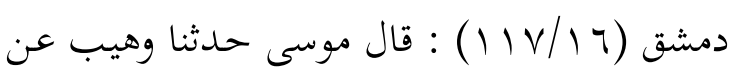

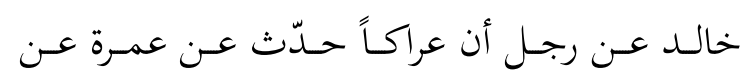

$$
\text { عائشة عن النبي. }
$$

فهنا قال :"عن عمرة ".

دراسة الإسناد :

- موسى بن إسماعيل أبو سلمة البصري تشTrYه6، روى له الجماعة، وقال عنه

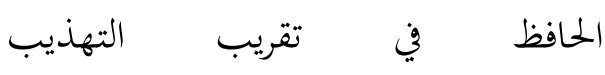

$$
\text { ( }
$$

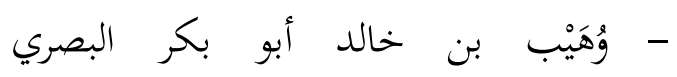

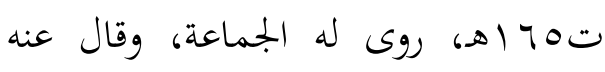

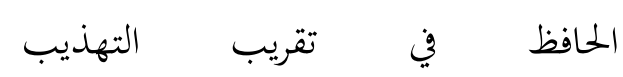

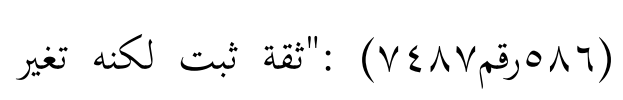

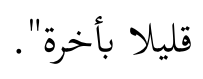$$
\text { - رجل : مبهم . }
$$

عراك بن مالك عن عائشة :"أن النبي أمر بخلائه أن يستقبل بـه القبلة لما بلغه أن النـاس يكرهون ذلك". فهنا قال : (عن رجل) فأهمه . إلا أن رواية البيهقي فيها :" عن رجل يقال

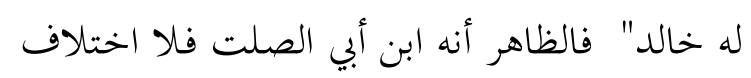

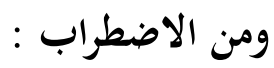

مـا أخرجهـ إسـحاق بـن راهويـه في المسـند

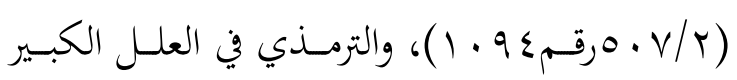

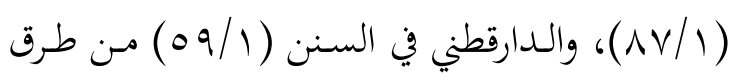
عن خالد الحذاء عن عراك عن عائشة عنها به نحوه فهنا لم يقل :"عن خالد بن أبي الصلت".

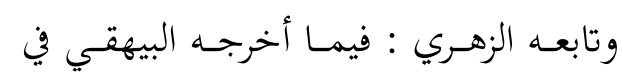

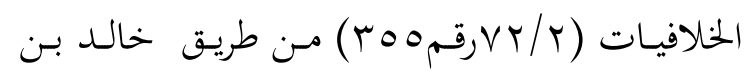
يهيى السدوسي عن يُمَّمَ بن إسحاق عن الزهري عن عراك بن مالك عن عائشة مرفوعاً مثله .

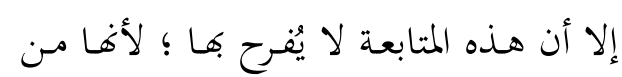

$$
\text { أوهام السدوسي. }
$$

قال البيهقي : " تفرد به خالد بن يهيى عن

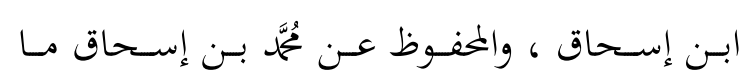
مضى من حديث جابر". 
إسناده ضعيف؛ للاختلاف في إسناده .

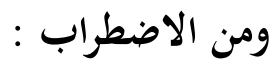

أخسـرج إسـحاق بــن راهويسه في المســند

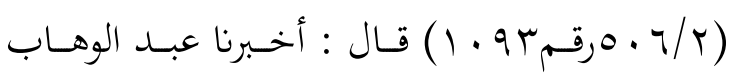

الثقفي، نا خالد الحـذاء، عن رجل، عن عمـر بـن

عبد العزيز، قال: ما استقبلت القبلة بفرجي منذ كذا

وكذا قال: فحدث ابن مالك :"أن رسول الله صلى

الله عليه وسلم لما بلغه أن الناس يكرهون ذلك أمر

بخلائه فاستقبل به القبلة".

فهنا : جعلاً مرسلاً .

دراسة الإسناد :

- - عبد الوهاب بن عبد المجيد أبو تُحَّم الثقفي

البصري تـ 9 اله، روى له الجماعة، وقال

عنه الحافظ في تقريب التهذيب (ص:

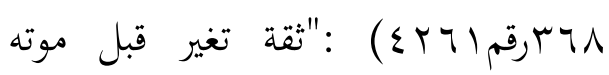

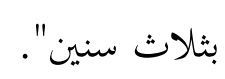

-

$$
\text { حكم الإسناد : }
$$

إسـناده ضعيف؛ للاخستلاف في إسـناده،

$$
\text { وفيه رجل مبهم · }
$$

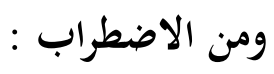

مـا أخرجــه البخـاري في التـاريخ الكبـير

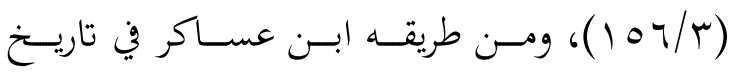

$$
\begin{aligned}
& \text { حكم الإسناد : } \\
& \text { إسناده ضعيف؛ فيه رجل مبهم، وفيه } \\
& \text { اختلاف في إسناده . }
\end{aligned}
$$

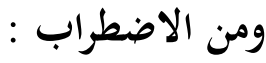

مــا أخرجسـه الطحساوي في معــاني الآثار

قال : ح ح ( اثنا علي بن أبي شيبة، ثنا يزيد

بن هارون، ثنا حماد بن سلمة، عن خالد الحـذاء، عن خالد بن أبي الصلت قال : كنا عند عمر بن عبد العزيز فذكروا الرجل يجلس على الخلاء فيستقبل القبلة فكرهوا ذلك فحدث عراك بن مالك عن عروة بن الزبير عن عائشة أن ذلك ذكر عند رسول الله فقال :" أوقد فعلوها ؟ حولوا مقعدتي إلى القبلة". فهنا ذكر "عروة" بين عراك وعائشة .

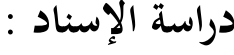

- علي بن أبي شيبة السدوسي مولاهم قال

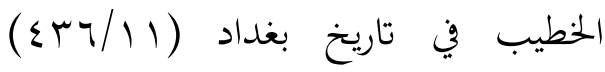
"روى عنه عبدالعزيز بن أحمد الغافقي بريخ وغيره من المصريين أحاديث مستقيمة تاريخ

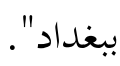
- - يزيد بن هارون أبو خالد الواسطي ت7 ·rه، روى له الجماعة، وقال عنه الحافظ في تقريب

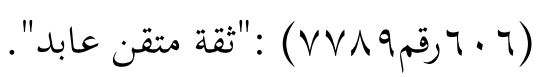




$$
\begin{aligned}
& \text { رواه حمـاد بـن سـلمة وهشـيم وعلـي بـن }
\end{aligned}
$$

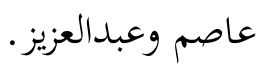

$$
\begin{aligned}
& \text { r- خالد الحـذاء عن رجل عن عراك عن } \\
& \text { عائشة مرفوعاً. } \\
& \text { رواه عنه الثقفي والسدوسي · } \\
& \text { ب- خالــ الحـذاء عـن عـراك عـن عائشــة }
\end{aligned}
$$

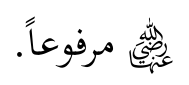

$$
\begin{aligned}
& \text { رواه عنه أبو عوانة ويجيى بن مطر والقاسم . }
\end{aligned}
$$

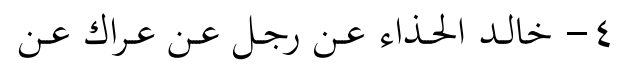

$$
\begin{aligned}
& \text { عمرة عن عائشة مرفوعاً . }
\end{aligned}
$$

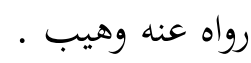

ه- خالد الحذاء عن خالد بن أبي الصلت عن عراك عن عروة عن عائشة مرفوعاً

$$
\text { رواه عنه حماد بن سلمة }
$$$$
\text { ج- خالـد الحـذاء عـن رجل عن عـراك بـن }
$$

$$
\text { مالك مرسلاً . }
$$$$
\text { رواه عنه عبد الوهاب الثقفي · }
$$

V - عراك عن عروة عن عائشة عِلّئِ قولها

$$
\begin{aligned}
& \text { رواه عنه جعفر بن ربيعه . } \\
& \text { وفي المتن : }
\end{aligned}
$$

مرة جعله موقوفاً . ومرة جعله مرفوعاً. .

المقصد الثالي : من أعل الحديث، ومن قواه، مع

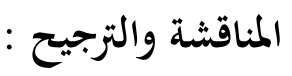

دمشـق (7 1 1 1 1 )، وأخرجـهـ أبسو حساتم في العلل

(Y ( / ) من طريقين عن بكر عن جعفر بن ربيعة

عـن عـراك عـن عـروة أن عائشـة كانـت تنكر قولمم "لا تستقبل القبلة".

فهنا قال :"عن عروة" وجعله موقوفاً .

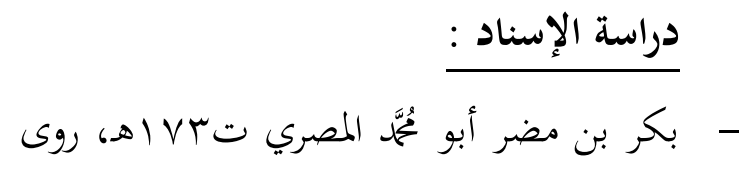
له الجماعة إلا ابن ماجه، وقال عنه الحافظ في

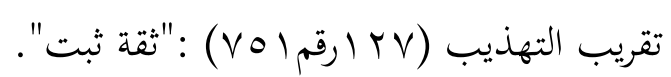
- - جعفر بن ربيعة أبو شرحبيل المصري ت7باره، روى له الجماعة، وقال عنه الحافظ في تقريب التهذيب

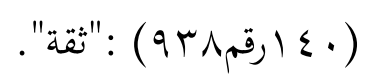

\section{حكم الإسناد :}

إسناده صحيح ·

قال البخاري :"هذ أصح".

وقال أبو حاتم كما في علل الحسديث ( "هذا أشبه".

\section{خلاصة الاضطراب :}

$$
\begin{aligned}
& \text { حصل الاضطراب في السند والمتن : } \\
& \text { فني السند : }
\end{aligned}
$$

عن عراك عن عائشة مرفوعاً. 
وقــــــــال الألبـــــــــن في الضـــــــيفة

( ) (

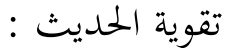

والحمديث قوّاه الإمام أحمد حيث قال :"

أمــا مـن ذهـب إلى حســيث عائشـة، فـإن مخرجـه

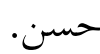

وقال غير أحمد : خالد معروف، قد روى

عنه خالد الحذاء والمبارك بن فضالة وواصل مولى أبي

عيينه.

نقله ابن المنذر في الأوسط (1/N/ وكذا

في التمهيد ( ( / + وزاد أنه عن الأثرم عن أحمد

ونقـل مغلطـاي في الأعـلام بسـتنه (1/ ق

rع () عن الإمـام أحمد أنه قال : أحسن مـا روى

في الرخصة حديث عراك وإن كان مرسلاً فإن مخرجه

مرسلاً كذا ذكره في المسند

وقال النووي في المجموع (r/T/إسناده

حسـن لكـن أشـار البخـاري في تاريخـهـ إلى أن فيسه

علة".

وقال مغلطاي على إسناد ابن ماجه والذي

هو الوجه الأول :"إسناده صحيح ظاهره الاتصال"

$$
\text { الإعلام بسنته (I V ) . }
$$

المناقشة والترجيح :

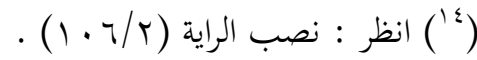

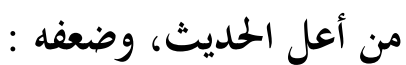

أعلـه الإمـام البخــاري بالاضطراب فقــال

"هذا حديث فيه اضطراب، والصحيح عن عائشة

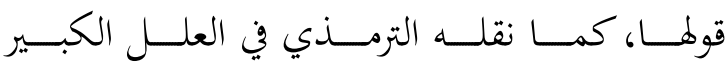

ورجح أبو حاتم الوقف وقال :" هذا أشبه

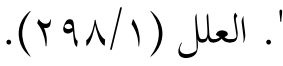

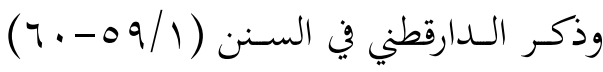

وفي العلل (ع / / آب) الاختلاف في سنده.

ورجــح الــدارقطني الوجــه الأول بقولــهـ

"الصحيح قول حماد بن سلمة ومن تابعه".

وضـعفه أبـو ثـــور، قــال ابـن المنـــر

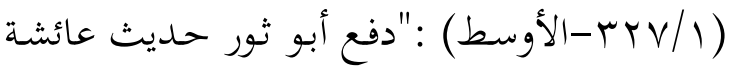

بأن قال :"خالد بن أبي الصلت : ليس بمعروف".

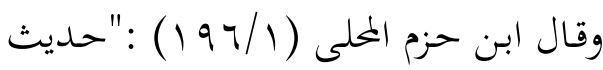

عائشة ساقط".

وقـال ابـن القيم الجوزيـة في مـذيب السـن

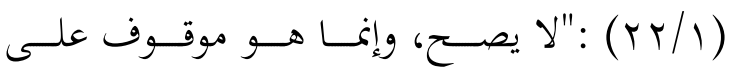

عائشة". وضعفه في زاد المعاد (r/ro/r) .

وقال الذهبي :"هذا حديث منكر". الميزان

$(r+r / 1)$ 
مالك المختص بـه الضـابط لحديثه جعفر بـن ربيعه الفقيه فرواه عن عراك عن عائشة أفها كانت تنكر ذلك فبين أن الحميث لعراك عن عروة ولم يرفعه ولا يجاوز به عائشة وجعفر بن ربيعة هو الحجة في عراك

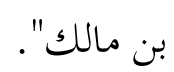

والذي يترجح أن الحديث ضعيف لا يصح • والموقوف هو الصحيح ·

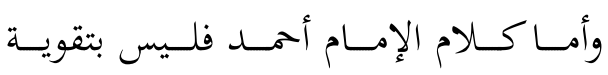

الحــــيث، قــال ابــن قـيم الجوزيــة في زاد المعــاد

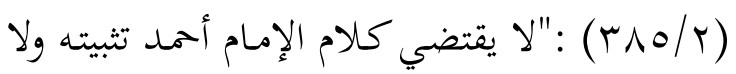
تحسينه".

وأمــا تقويسة النسووي ومغلطــاي رحمهمـا الله

تعالى فلا تصحّ؛ لأن في إسناد الحـديث اضطراباً : بمثله لا يمكن القول بثبوت الحديث.

الخاتمة

وفي ختـام هـذا البحـث آمـل أن أكـون قـد

أعطيت الحمديث حقهـ ومستحقه مـن جهة البحثث والتنقيب عن طرقه وعلله ،وأسجل هنا بعض النتائج المستخلصة من البحث . - أن علة الحديث لا تدرك إلا بعد جمع طرقه

$$
\text { والتفتيش عن رجاله . - و }
$$

- أن علـة الحــديث قـــ تكـون غامضــة فـلا

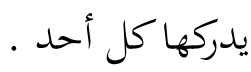

الأوجــه السـتة الأولى مــدارها علـى خالـــ الحذاء .

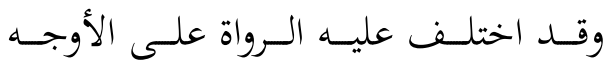
السابقة؛ فالظاهر أنه اضطرب فيه ولم يضبطه . وذهـب الـدارقطني في السـنـ (1/ • ـ ) إلى أن الوجـهـ الأول هـو الصـواب فتــال :" هـــا أضـبط إسناد وزاد فيه خالد بن أبي الصلت وهو الصواب".

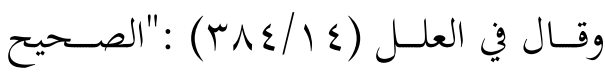
قول حماد بن سلمة، ومن تابعة"، وكذا البيهقي في

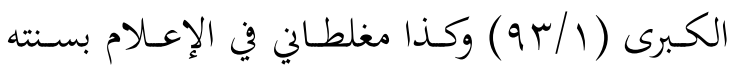

وخـالف جعفـر بـن ربيعـة : خالـد بـن أبي الصلت فرواه موقوفاً على عائشة قال البخاري :"الصحيح عن عائشة قوها" العلل الكبير (1/1 (9-للترمذي).

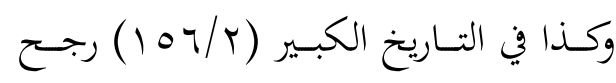
الوقف، وقال :"هذا أصح".

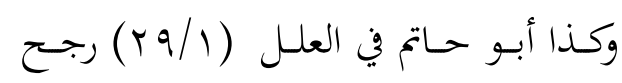
الوقف وقال :"هذا أشبه". ورجـح ابـن قيم الجوزيـة وقفـه على عائشـة وقـال كمـا مختصـر سـنن أبي داود ( ( T/ ) :" قـال بعض الحفـاظ هـذا حـديث لا يصـح ، وله علـة لا يـركها إلا المعتنـون بالصـناعة المعانون عليها وذلك أن خالـد بـن أبي الصـلت لم يهفـظ متنسه ولا أقـام إسـناده خالفـه فيـه الثقــة الثبـت صـاحب عـراك بـن 
7. خالـد الحـذاء عـن رجـل عـن

عراك بن مالك مرسلاً .

V. عـراك عـن عـروة عـن عائشـة

عزبِّيّ قوها

- ـ وهذه الأوجه الستة المختلفة لا يمكن معها

الترجسيح أو الجمـع مــا يشعر بعـدم ضـبطه

لمذا الحمديث.

- أن الوجــه الســابع هـو الـراجح؛ لصـحة

$$
\text { إسناده وسلامته من الاختلاف. }
$$

- أن مـن صـحح الحسديث لم ينتبـه للعلـل الحاصلة في إسناده ومتنه.

- أن مـن ضـعف الحسديث فقـــ أصـاب في

$$
\text { تضعيفه . }
$$

- أنسه عنــــ اخـــلاف العلمـاء في الحــديث

تصــحيحاً وتضـعيفاً يـرجح بــن أقــوالهم

حسب القواعد المقررة في علم الحديث .

\section{فهرس المصادر والمراجع}

- - الأحكام الوسطى من حديث الببي، لعبدالحق

بن عبدالرحمن الإشبيلي، تحقيق حمدي السلفي

وصببحي السـامرائي، مكتبـة الرشـد، الرياض،

.

- الاسـتذكار لمـذاهب فقهـاء الأمصـار وعلمـاء

الأقطار فيمـا تضمنه الموطـأ مـن معـاني الرأي

والآثار، لأبي عمــــر يوســف ابــن عبـــدالبر
- أهميـة دراسـة علل الحـديث والوقـوف على تصرفات الأئمة في المضايق . - أن التخريج الغرض منه بيان حال الحميث لا بجرد العزو دون بيان الحكم .

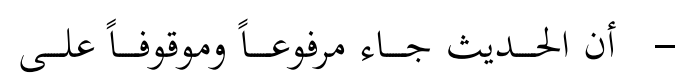

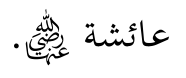
- أن الحديث ضعيف لا يصح . - أن الموقـوف على عائشـة هــو الصـحيح الثابت - أن الحسلـيث رواه خالــ الحــذاء على سـتة

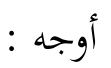
ا ـ خالـد الحـذاء عـن خالـد بـن أبي الصـلت عـن عـراك عـن عائشة مرفوعاً. r. خالــ الحـذاء عـن رجـل عـن عراك عن عائشة مرفوعاً. r. خالـد الحـذاء عـن عـراك عـن عائشة عِنِّيْ مرفوعاً. ع. خ خالـد الحـذاء عـن رجـل عـن عـراك عـن عمـرة عن عائشـة

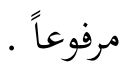
ه. ـالـد الحـذاء عـن خالـد بـن أبي الصـلت عـن عـراك عـن عروة عن عائشة مرفوعاً. . 
- الـرياض ، تحقيـق : صـغير الباكسـتاني ،

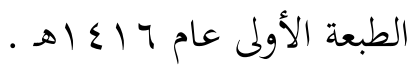
للعلامة الحافظ أبي عمر يوسف بن عبدالله بن عبد البر النمري القرطبي، تحقيق مصطفى بن أحمـد العلـوى و عُحَّه عبــ الكبـير البكــىى، دار

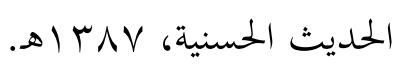

- مـــيب الكمــال في أسمــاء الرجـال تأليـف :

يوسف بن عبد الرحمن المزي ت ع Vه تحقيق بشـار عــواد الطعبـة الثانيـة عــام ب مــ اهـ

$$
\text { مؤسسة الرسالة بيروت . }
$$

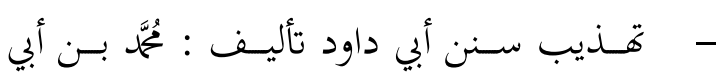
بكر المعروف بابن قيم الجوزية ت 0101 كه ، تحقيق :أحمد شاكر و عُمَّم الفقي ، دار المعرفة

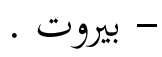
- الثقـات : تأليـف : أبي حساتم عُمَّمَ بـن حبـان البستي ، مراقبة مُحَّم عبد المعيد خحان ، مطبعة مجلس دائرة المعارف العثمانية - الهند ، الطبعة الأولى عام rq r اهـ- V • ع اهـ. - - الجامع لأخلاق الراوي وآداب السامع تأليف : أحمد بن علي الخطيب البغدادي تهبحـه ، تحقيق : محمود الطحان ، مكتبة المعارف الرياض ، الطبعة الأولى عام ب • ع اهـ ـ.

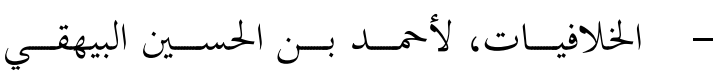
ت10 عـهـ، تحقيـق : مشـهور بـن حسـن،
النميري، تحقيق علي ناصف، الجمهورية العربية المتحدة، المجلس الأعلى للشّّؤون الإسلامية. - - الاعتبار في الناسخ والمنسوخ من الآثار : لأبي

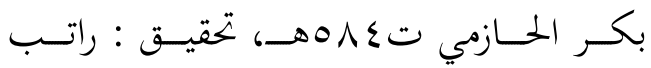
حاكمي، مطبعة الأندلس ، حمص ، الطبعة

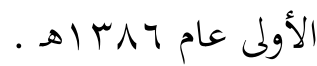
- الإعـلام بسـنته عليـهـ السـلام تأليـف : عـلاء الدين مغلطاي بن قليج الحنفي ت Y VI VI ، تحقيق : كامل عويضـة ، مكتبـة نزار البـار مكة ، الطبعة الأولى 91 إ اهـ ـ - - التـاريخ الكبــير، للإمـام البخـاري أبي عبـــ الله مُحَّمَ بـن إسماعيـل، مصـورة عـن دائرة المعـارف العثمانية، إ؟9 اهـ. - تاريخ بغداد تأليف : أحمد بن علي الخطيب البغدادي طبعة دار الكتاب العربي - بيروت . - تاريـخ دمشـق تأليـف : علي بـن الحسـن أبي القاسم ابن عساكر الشافعي ت هـ ل Vهـ ، تحقيق : عمـر العمـروي ، طبعة دار الفكر -

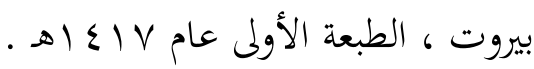
- تاريـخ واسـط: لأسـلم بـن سـهل الواسـطي · تحقيق : كوركيس عواد ـ تصوير عامج . ـ اهـ . عالم الكتب - بيروت . - تقريب التهذيب تأليف : أحمد بن علي ابن حجر العستلاني ت 10 1هـ ، دار العاصـمة 
- علـل الحـــيث ، لعبــ الـرحمن ابـن أبي حـاتم

الـرازي تV rrهـ ، أ- تحقيـق: محسب الـدين

ب. تصــوير دار المعرفــة ، بــيروت : تص

الخطيـبـ

$. \$ 1 \leqslant .0$

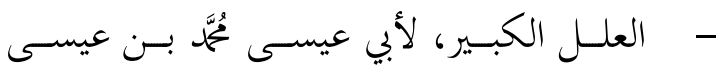

الترمـذي، ترتيـب أبي طالـب القاضي، تحقيـق

حمزة ديب مصطفى، مكتبة الأقصى، عمان،

الأردن، الطبعة الأولى، 7 · ـ اهـ.

- العلل تأليف : علي بن عمر الدارقطني تحقيق

: محــوظ الـرحمن السـلفي الطبعـة الأولى عـام

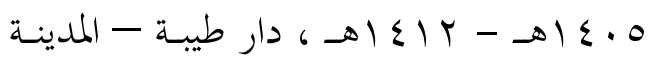

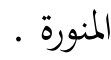

- -

ابن عـدي ، تحقيق : سهيل زكار و تـدقيق :

يهيى غـزاوي ، الطبعـة الثالثـة و ، ع اهـ ، دار

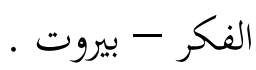

- المجموع شرح المهذب تأليف : يهيى بن شرف

النووي ت TV Tهـ ، دار الفكر .

- المحلى : لأبي عُمَّمَ علي بن أحمد بن سعيد ابن

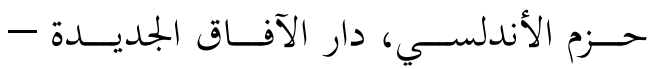

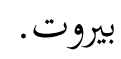

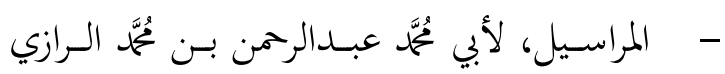

ت VYr Tهـ، تحقيـق : شـكر الله قوجــاتي،

الطبعـة الثانيـة 11 إ اهـ، مؤسسـة الرسـالة -
الطبعة الأولى عـام \& إ اهـ، دار الصميعي -

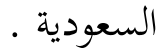

- ماد المعـاد في هـدي خير العبـاد، للإمـام شمس

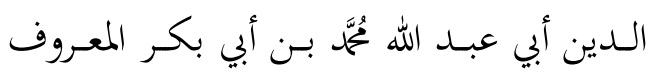

بابسن قـيم الجوزيـة الدمشـقي، تحقـق شعيب الأرناؤوط وعبـــ القــادر الأرناؤوط، مؤسّســة الرّســالة، بــيروت، لبنــان، الطبعــة الثالثـة، $.81 \varepsilon \cdot 9$ الألبـاني، المكتـب الإسـلامي، الطبعـة الأولى، $.81 \% 99$ - - ســن الـدارقطني أبي الحســن علـي عمــر ت مراهـ ، طبع في مطبعة فالكن ، لاهور -

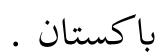

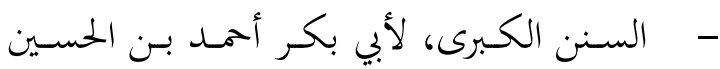
البيهقي ، دار المعرفة للطباعة والنشر، بيروت مطبعة بجلس دائرة المعارف النظامية العثمانية، حيدر آباد الدكن، الهند، ع ع اهـ.

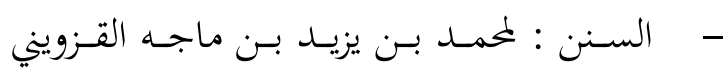
تحقيق : فواز زمرلي والسبع ، ط : دار الريان ،

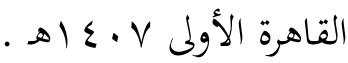

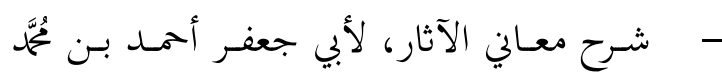
بـن سـلامة الطحساوي، حققـه وضبطه ونسته

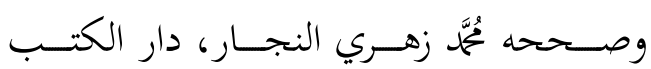
العلمية، الطبعة الأولى، 99 ب اهـ. 
- - المغني تأليـف : أبي عُمَّمّ عبـد الله بـن أحمـل بـن

مُحَّمَ ابن قدامـة المقدسي ت · ب rآهـ تحقيق : عبد الفتاح الحلو ، الطبعة الثانية با إ اهـ ،

$$
\text { دار هجر - القاهرة . }
$$

- ميززان الاعتـدال في نقـد الرجـال تأليـف : مُعَّم

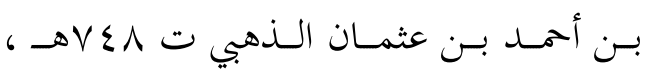
تحقيـق : علـي تُمَّمَ البجــاوي ، دار المعرفـة بيروت ، الطبعة الأولى عام ب إـ اهـ .

- ناسخ الحديث ومنسوخه ، لأبي حفص عمر بن أحمـد ابن شـاهين ت مربهـ ، تحقيق : سمير الزهيري ، الطبعة الأولى عام م ·ـ اهـ ،

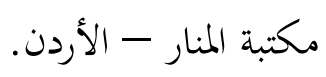
- - نصب الراية لأحاديث الهداية تأليف : عبد الله

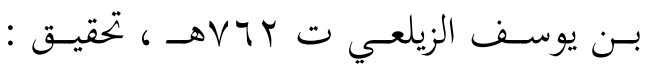

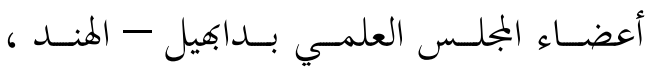
الطبعــة الثالثـة عــام V · ع اهـــ ، دار إحيـاء

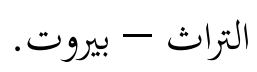

- مســد أبي داود الطيالسي، لسـليمان بـن داود بن الجارود الطيالسي، دار المعرفة، بيروت. - مسند إسحاق بن راهوية ت م مبrهـ ، تحقيق : عبـــ الغفـور البلوشـي ، الطبعـة الأولى عـام با إ اهـ ، دار الإيمان - المدينة النبوية . - - مسند أمير المؤمنين عمر بن عبد العزيز ، لأبي لي لئ

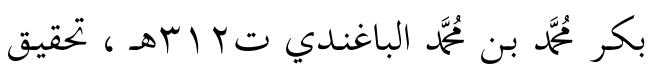

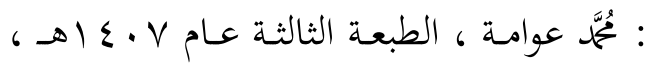
دار ابن كثير - دمشق . - مثن

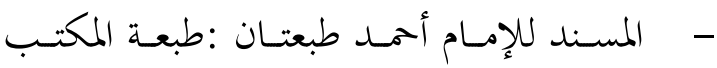
الإسلامي، بيروت - لبنان. شيبة الكوفي ت هبrهـ تحقيق : عُمَّم شاهين ، الطبعـة الأولى عـام 7 إـ اهـ ، دار الكتـب

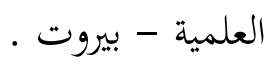

- معرفة علوم الحـديث تأليـف: أبي عبـد الله عُمَّم بن عبد الله الحاكم النيسابوري تحقيق : السيد معظمبم حســين ، المكتبـة العلميـة - المدينـة ، الطبعة الثانية عام V Y T اهـ . 